\title{
Large ungulates from the basal Oligocene of Oman: 1 - Embrithopoda
}

\section{Martin PICKFORD}

Sorbonne Universités - CR2P, MNHN, CNRS, UPMC - Paris VI, 8, rue Buffon, 75005, Paris, France; pickford@mnhn.fr

Pickford, M. 2015. Large ungulates from the basal Oligocene of Oman: 1 - Embrithopoda. [Grandes ungulados del Oligoceno basal de Oman: 1- Embrithopoda]. Spanish Journal of Palaeontology, 30 (1), 33-42.

\begin{abstract}
Arsinoitheres (Embrithopoda, Mammalia) have been known to occur in the Early Oligocene of Oman since 1992, yet the fossils on which the records were based have not yet been published. This contribution rectifies this situation and provides the first secure basis for the presence of arsinoitheres in Oman, some post-cranial material previously attributed to this genus being of uncertain affinities. The Omani records and the one in the Shumaysi Formation, Saudi Arabia, extend the distribution of Arsinoitherium andrewsi to the northeastern extremities of the Afro-Arabian Continent.
\end{abstract}

Keywords: Arsinoitherium, Embrithopoda, Oligocene, Oman, biogeography.

\section{RESUMEN}

Arsinoitheres (Embrithopoda, Mammalia) se han reconocido en el Oligoceno Temprano de Oman desde 1992, aunque los fósiles en los que están basados estos registros aún no han sido publicados. Este trabajo solventa esta situación y proporciona la primera base segura de la presecia de arsinoitheres en Oman, algún material post-craneal atribuido previamente a este género de afinidades inciertas. El registro de Oman y el de la Formación Shumaysi, Arabia Saudi, extiende la distribution of Arsinoitherium andrewsi a las extremidades del noroeste del Continente Afro-Arabia.

Palabras clave: Arsinoitherium, Embrithopoda, Oligoceno, Oman, biogeografia. 


\section{INTRODUCTION}

The genus Arsinoitherium was first recorded in Oman by Thomas et al. (1992) and Roger et al. (1993, 1994), but the fossils were not described, featuring only in a faunal list. The various teeth upon which basis Thomas et al. (1992) listed the genus Arsinoitherium in the Early Oligocene of Oman are described herein and the biogeographic implications of the fossils are discussed. A fossil ulna attributed to Arsinoitherium by Al Sayigh et al. (2008) is too small to belong Arsinoitherium andrewsi and it could represent Omanitherium or Arcanotherium (or Numidotherium) rather than to Arsinoitherium.

\section{GEOLOGICAL AND PALAEOENVIRONMENTAL CONTEXTS}

The fossils described herein came from two localities in the Dhofar region of Oman, Taqah (TQ) near Wadi Darbat east of Salalah, some 30 metres above sea-level, and Thaytiniti (TH) west of Salalah at an altitude of over 900 metres. Two sub-localities in Thaytiniti (TH 1 and TH 2) yielded remains of arsinoitheres (Fig. 1).

The geological and stratigraphic context of the Dhofar fossils was established by Thomas et al. (1989, 1992, 1999). There is general acceptance of the correlations proposed by these authors, that Thaytiniti dates from the base of the Rupelian, and Taqah from slightly later in the Rupelian (Fig. 2) Coster et al. (2012).

Fossil freshwater gastropods and land snails from coeval deposits in the same regions show strong African affinities (Pickford et al., 2014) and indicate a sub-humid savannah ecosystem interspersed with swamps and stands

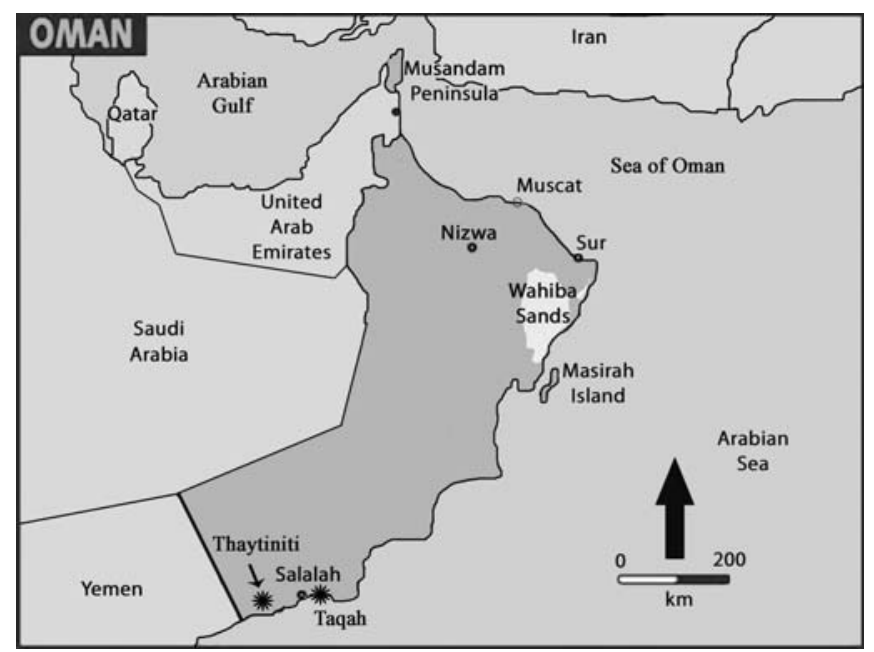

Figure 1. Location of Thaytiniti and Taqah, Oman. of dense woodland, close to the ancient sea shore. Like their Egyptian relatives, the Omani arsinoitheres lived near the sea, their remains often being found close to, or within, sediments yielding marine and brackish water molluscs and foraminifers.

\section{MATERIALS AND METHODS}

The fossils described herein are curated at the Oman Natural History Museum, Muscat, Oman (ONHM). Comparisons were made with fossils stored at the Natural History Museum, London (NHMUK) and the Muséum National d'Histoire Naturelle, Paris (MNHN).

Specimens were measured with sliding calipers to the nearest $0.1 \mathrm{~mm}$. Images were acquired with a Sony Cybershot 16.1 megapixel camera and treated with Photoshop Elements 3 to increase contrast and to remove unwanted background. Scale bars were added manually as it has been found that a combination of parallax and digital effects can result in inaccurate scaling based on scales included with the fossil at the time of image acquisition.

Dental nomenclature of arsinoithere teeth was defined by Court (1992a). Upper teeth are identified by capital letters $\mathrm{P}$ - premolar, $\mathrm{M}$ - molar, lower teeth are in lower case letters $p$ - premolar, $\mathrm{m}$ - molar. In addition, in order to avoid misprints or typographic errors, the upper teeth have a forward slash (which represents the occlusal surface) after the merisitic position (P4/ - upper fourth premolar, $\mathrm{M} 1$ / - upper first molar), for the lower teeth the slash is before the meristic position ( $\mathrm{p} / 1$ - lower first premolar; $\mathrm{m} / 3$ - lower third molar).

\subsection{Fossil arsinoithere dental elements from Oman described in this paper}

Thaytiniti - ONHM TN 1992-3, lingual half of right P4/; ONHM TN 1992-1, distal half of left lower molar; ONHM TH 7 - distal enamel of a left M3/.

Taqah - ONHM TQ 1992-1, left m/3; ONHM TQ 19922, right M1/ heavily worn; ONHM TQ 1992-3, left p/1.

\section{SYSTEMATIC PALAEONTOLOGY}

Order EMBRITHOPODA Andrews, 1906

Family Arsinoitheriidae Andrews, 1904

Genus Arsinoitherium Beadnell, 1902a 


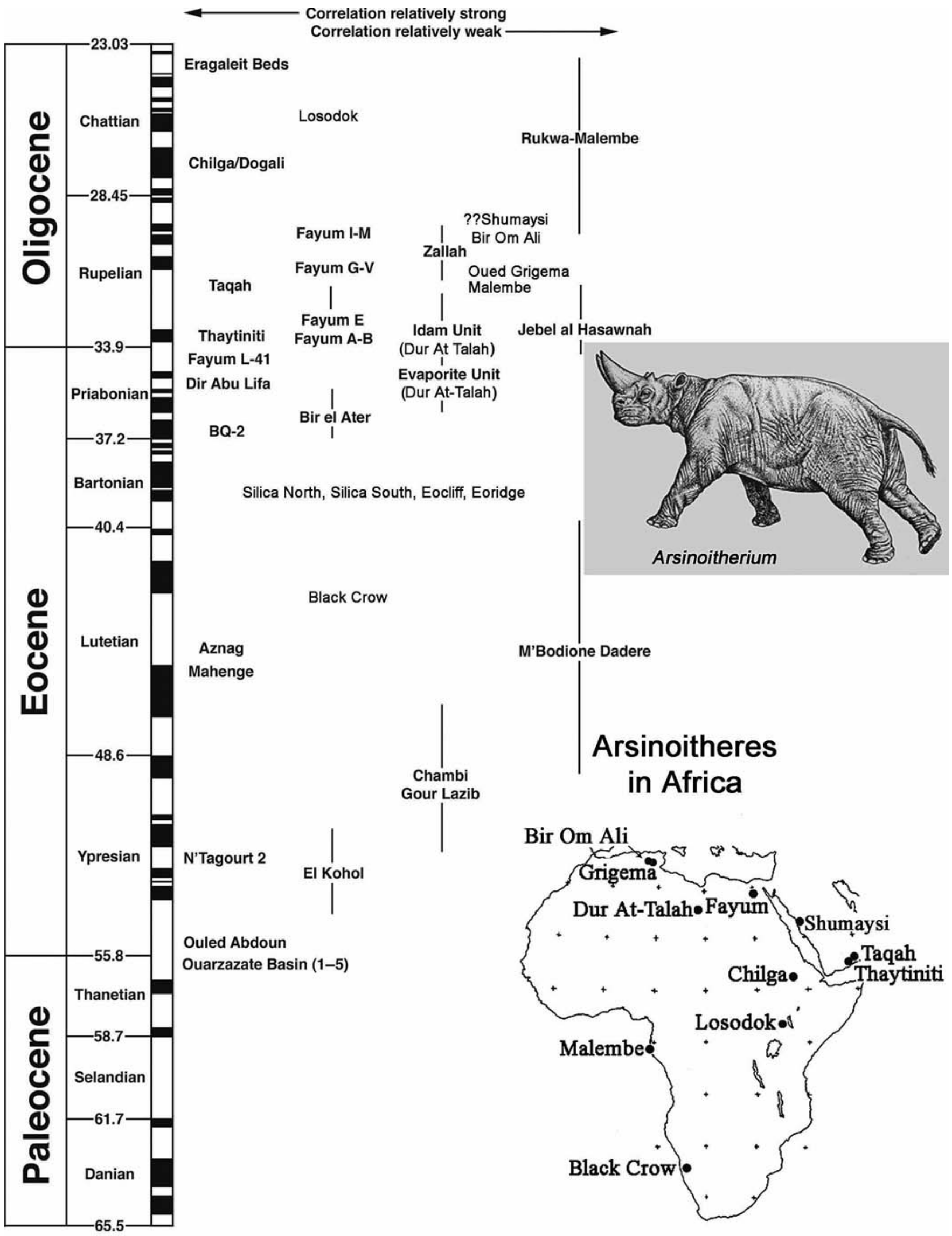

Figure 2. Geographic and stratigraphic distribution of arsinoitheres in Afro-Arabia. Shumaysi Early Oligocene (Zalmout et al., 2012). Time scale is from Seiffert (2010) with new content added. 
Genus diagnosis. For genus diagnosis of Arsinoitherium, see Sanders et al. (2010).

Arsinoitherium andrewsi Lankester, 1903

Species diagnosis. Large species of Arsinoitherium in which the upper premolars show the medifossette opening lingually and closed distally, and the $m / 3$ exhibits a distinct and well-developed hook-like talonid behind the distal lophid.

\section{Description.}

Upper dentition. $\mathrm{P} 4 /$ is represented by a moderately worn tooth lacking the ectoloph (ONHM TN 1992-3) (Fig. 3.1). The mesial cingulum extends across the front of the tooth from the parastyle. There is a deep valley between this cingulum and the protocone, which is a large rounded bulbous cusp, decapitated by wear. There is a distinct waist between the protocone and the paracone + parastyle marked by the protocone-paracone groove. Behind the protocone there is a valley, which separates it from the hypocone. Buccal to the hypocone is the metacone from which it is separated by a waist, corresponding to the groove on the anterior aspect of the hypocone and metacone. The fossette (here termed the medifossette) between the protoloph (parastyle + paracone + protocone) and the distoloph (mesostyle + metacone + hypocone) is capacious and deep and opens lingually at the lingual notch. There are three roots on the lingual side.

The right M1/ (ONHM TQ 1992-2) is deeply worn, leaving little detail of the crown morphology (Fig. 4.2). Nevertheless, the deep valley between the parastyle and mesostyle is evident, as are the depths of the fossettes in front of and behind the protocone, the one in front being bordered anteriorly by the mesial cingulum, the one behind (the medifossette) by the hypocone.

ONHM TH 7 was compared with teeth in situ in skulls housed in the NHMUK, London, and the MNHN, Paris, and is compatible with the distal enamel surface of a left third upper molar (Fig. 3.2). It is close in morphology and dimensions to Arsinoitherium andrewsi and Arsinoitherium zitteli from the Fayum, Egypt (Tables 1 and 2). The enamel is concave on the lingual part of the distal loph and convex on the buccal side. On this basis the Thaytiniti specimen is likely to be from the left side. The specimen is moderately worn, the remaining crown height being 74 $\mathrm{mm}$, compared with an unworn crown height on 106.5 $\mathrm{mm}$ in NHMUK M 8825. Even with this crown height, the Thaytiniti arsinoithere is exceptionally hypsodont, a feature that distinguishes Arsinoitherium from other embrithopods such as Namatherium (Pickford et al., 2008). The enamel surface is very lightly rugose, with clear alternating stripes of enamel typical of arsinoitheres (von Koenigswald, 2013). Enamel is thin (1.7 $\mathrm{mm}$ at the occlusal surface) as in the Egyptian species.
Table 1. Measurements (in $\mathrm{mm}$ ) of arsinoithere $\mathrm{M} 3 / \mathrm{s}$ from Oman and Egypt.

\begin{tabular}{cll}
\hline \multicolumn{1}{c}{ Catalogue } & \multicolumn{1}{c}{ Tooth } & $\begin{array}{c}\text { Height of } \\
\text { distal enamel }\end{array}$ \\
\hline NHML M 8825 & Right M3/ unworn & 106.5 \\
NHML M 8802 & Right M3/ lightly worn & 94.5 \\
ONHM TH 7 & Left M3/ medium worn & 74 \\
\hline
\end{tabular}

Table 2. Measurements (in $\mathrm{mm}$ ) of the teeth of Omani Arsinoitherium andrewsi.

\begin{tabular}{clcc}
\hline \multicolumn{1}{c}{ Catalogue N $^{\circ}$} & \multicolumn{1}{c}{ Tooth } & $\begin{array}{c}\text { Mesio- } \\
\text { distal } \\
\text { length }\end{array}$ & $\begin{array}{c}\text { Bucco- } \\
\text { lingual } \\
\text { breadth }\end{array}$ \\
\hline ONHM TQ 1992-1 & Left m/3 & 70.7 & 41.8 \\
ONHM TQ 1992-2 & Right M1/ & 52.0 & 50.0 \\
ONHM TQ 1992-3 & Left p/1 & 17.7 & 18.0 \\
ONHM TN 1992-1 & Left m/2 & -- & 34.6 \\
& rear lophid & & \\
ONHM TN 1992-3 & Right P4/ & 36.1 & -- \\
\hline
\end{tabular}

Lower dentition. The $\mathrm{p} / 1$ from Taqah (ONHM TQ 1992-3) is well preserved with moderate wear (Fig. 4.1). The single root marks this tooth as the anterior premolar, the other premolars being double-rooted (Andrews, 1906; Court, 1992a). The buccal wall of the tooth has a prominent groove running from the apex towards the root but stopping short of the cervix. The lingual side of the tooth has strong, sharp, preparaconid and postentoconid cristids descending towards the short lingual cingulum; and there is a metaconid crest opposite the buccal groove. The enamel extends much further rootwards buccally than lingually, but mesially and distally the profiles of the cervix are the same.

The transversely oriented distal lophid of the lower molar, probably a second lower molar (ONHM TN 1992-1) has a prehypocristid which is directed mesiolingually from the midline of the tooth towards the lingual side of the median transverse valley (Fig. 3.3). There is a strong distal cingulum which descends in altitude from the lingual to the buccal side of the tooth. The cervix is thus considerably higher on the lingual side than it is on the buccal side.

The Taqah m/3 (ONHM TQ 1992-1) is bilophodont with a well-developed talonid positioned to the lingual side of the midline of the crown and well separated from the distal lophid (Fig. 4.3). The talonid is narrower bucco-lingually than the two anterior lophids. The preprotocristid descends mesio-buccally to fuse with the mesial cingulum. The premetacristid descends mesially and only slightly buccally, joining the mesial cingulum quite close to the lingual margin of the crown. The mesial lophid is slightly obliquely oriented such that the protoconid is more anteriorly positioned than the metaconid. The second lophid shows a similar slightly oblique arrangement between the hypoconid and the 

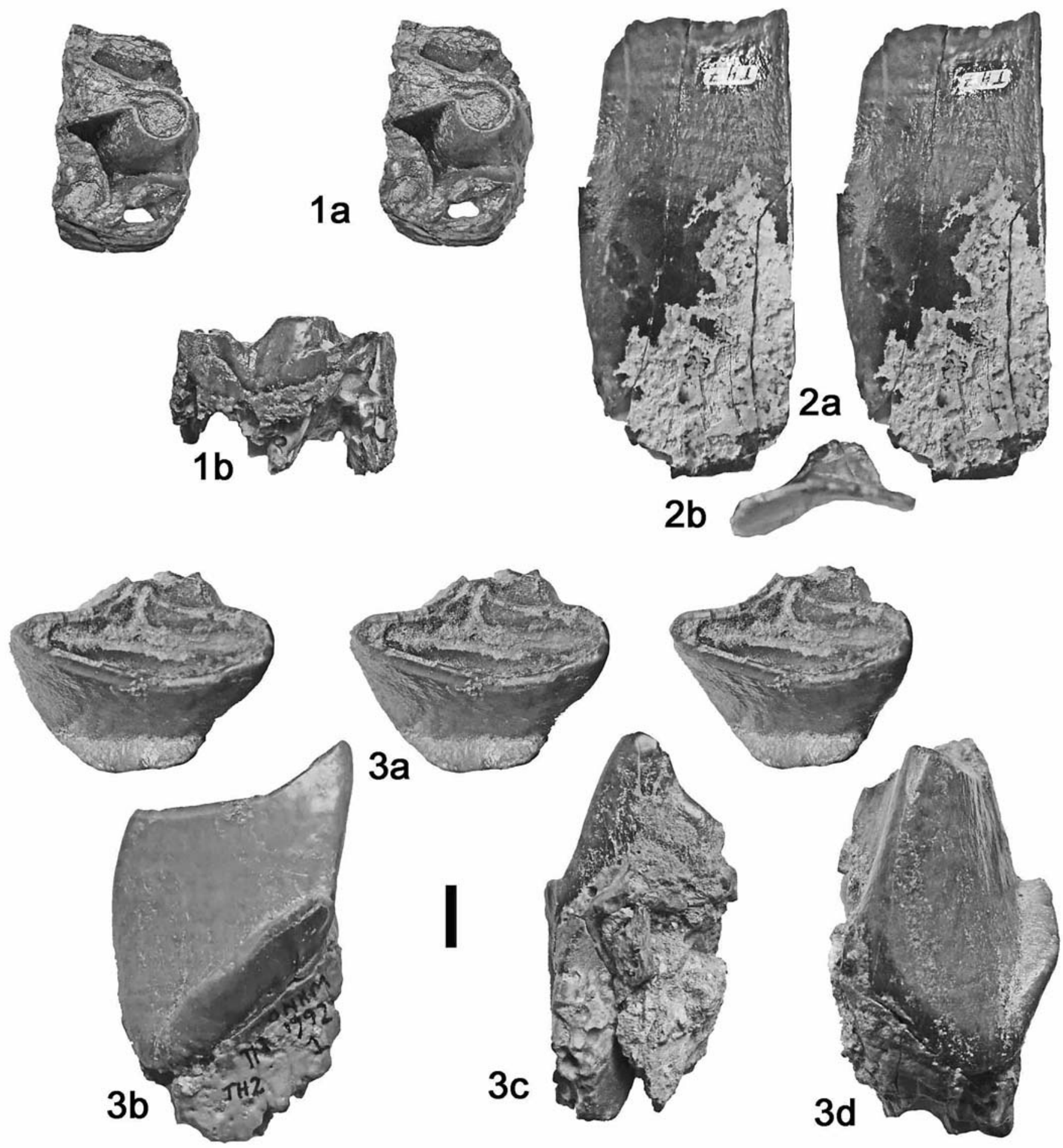

Figure 3. Arsinoitherium andrewsi from Thaytiniti, Oman. 1) ONHM TN 1992-3, lingual portion of a right P4/, (1a) stereo occlusal view, (1b) lingual view. 2) ONHM TH 7, part of the rear loph of a left M3/, (2a) distal stereo view, (2b) occlusal view to show thin enamel and concavo-convex curvature of the distal surface. 3) ONHM TN 1992-1, distal lophid of a left lower molar (probably m/2) from locality TH 2, (3a) stereo triplet of the occlusal view, (3b) distal view, (3c) lingual view, (3d) buccal view (scale: $10 \mathrm{~mm}$ ). 
entoconid. The prehypocristid departs from the midline of the tooth towards the lingual side of the median transverse valley blocking its lingual end. There is a strong wear facet along this cristid. The hook-like talonid is prominent, is well separated from the second lophid, is about half the height of the other cusps, and about half the breadth of the tooth.

\section{DISCUSSION}

Sanders et al. (2010) concluded that there was a single species of Arsinoitherium in the Fayum sequence. However, there are two upper premolar morphotypes and two $\mathrm{m} / 3$ morphotypes in the available samples, indicating the presence of two taxa, the differences noted being outside the usual range of variation related to sexual dimorphism.

The $\mathrm{P} 4 /$ from Thaytiniti, even though incomplete, closely matches the P4/ in NHMUK M 8463 (Andrews, 1906, pl. 2; Court, 1992b, pl. 2) but is radically different from the P4/ in NHMUK M 8461 (the holotype of Arsinoitherium zitteli) illustrated by Andrews (1906, text-fig.6, pl. 4) and Court (1992a, fig. 2) (Fig. 4). In the former the medifossette opens lingually and is walled off distally, whereas in the latter, the medifossette opens distally and is walled off lingually. Such differences are not due to different stages of wear, and are unlikely to be due to sexual dimorphism. They reflect divergent functional occlusal relationships between the upper and lower premolars, implying different ways of mastication (Court, 1992a).

Lower third molars of arsinoitheres from the Fayum, Egypt, illustrated by Andrews (1906) and Court (1992a) show poorly developed talonids which are little more than distal cingula not projecting very far distally. A specimen curated in the MNHN, Paris, however, shows a prominent hook-like talonid in the $\mathrm{m} / 3$ located in the lingual half of the tooth (Mondegar Fernandez et al., 2008). The difference in $\mathrm{m} / 3$ talonid development in some specimens from the Fayum and that from Taqah is probably of taxonomic significance. The question needs to be examined in greater detail, but the morphological variability in the material currently classified in Arsinoitherium zitteli by Sanders et al. (2010) is too great for all of it to belong to a single species. The validity of a second species Arsinoitherium andrewsi is accepted here, and the Omani material is attributed to this second taxon.

\subsection{Diversity in Fayum arsinoitheres}

Sanders et al. (2010) considered that Arsinoitherium andrewsi Lankester, 1903, was a junior synonym of Arsinoitherium zitteli Beadnell, 1902a (1902b). However, there is significant morphological varaibility among the specimens previously identified as Arsinoitherium zitteli. There are two kinds of talonid in the $\mathrm{m} / 3$, one with an elongated hook-like talonid well separated from the posterior lophid, and positioned on the lingual side of the crown. In addition there are two kinds of $\mathrm{P} 4 /$ in the specimens from the Fayum, one in which the medifossette opens lingually, the other in which the medifossette opens distally. On the basis of post-cranial bones, Arsinoitherium andrewsi is a much larger species than $A$. zitteli as demonstrated by Andrews (1906) and confirmed by Mondegar Fernandez et al. (2008). The Taqah and Thaytiniti embrithopod fossils are close in morphology and dimensions to specimens attributed to Arsinoitherium from the Fayum, Egypt (Andrews, 1906; Court, 1992a, b) but on the basis of their morphology they are considered to belong to the second form of arsinothere represented in the Fayum, Arsinoitherium andrewsi. Until better material is found, some doubt will persist concerning the identification of the species present in Oman, although the balance of the available evidence $(\mathrm{P} 4 /$ and $\mathrm{m} / 3$ morphology) suggests that it does not represent $A$. zitteli, in which case it is likely to belong to $A$. andrewsi or less likely to an undescribed species. Pending the recovery of additional material, the author prefers to attribute the Omani material to an existing taxon, rather than to erect a new species.

In summary it is not known whether the differences in upper premolar morphology and $\mathrm{m} / 3$ talonid development reflect species differences, or a peculiar form of polymorphism. If the former is the case, then the upper premolars in which the medifossette opens lingually could represent Arsinoitherium andrewsi. The upper premolars in which the medifossette opens distally belong to Arsinoitherium zittelli, as this morphotype occurs in the holotype (Andrews, 1906). The $\mathrm{m} / 3$ with well-developed talonid would belong to Arsinoitherium andrewsi, and those with only a distal cingulum would belong to Arsinoitherium zitteli. But to resolve the uncertainty, associated material is required.

A fossil ulna from the Dhofar region of Oman was attributed to Arsinoitherium Al-Sayigh et al. (2008). However, examination of the specimen, which is curated at the Sultan Qaboos University, Muscat, reveals that it is too small to belong to Arsinoitherium zitteli or Arsinoitherium andrewsi. It is however, compatible in dimensions with the proboscidean (barytherioid?) Omanitherium found in the same region (Seiffert et al., 2012) and it is here considered more likely to belong to this genus, or to Arcanotherium Delmer (2009) than to an embrithopod or to Barytherium.

Doubts have been raised about the validity of Arsinoitherium giganteum from Chilga, Ethiopia (Mondegar Fernandez et al., 2008), as it appears that the main difference from Arsinoitherium zitteli concerns its supposedly greater dental dimensions and differences in post-cranial proportions (Sanders et al., 2004). However, 

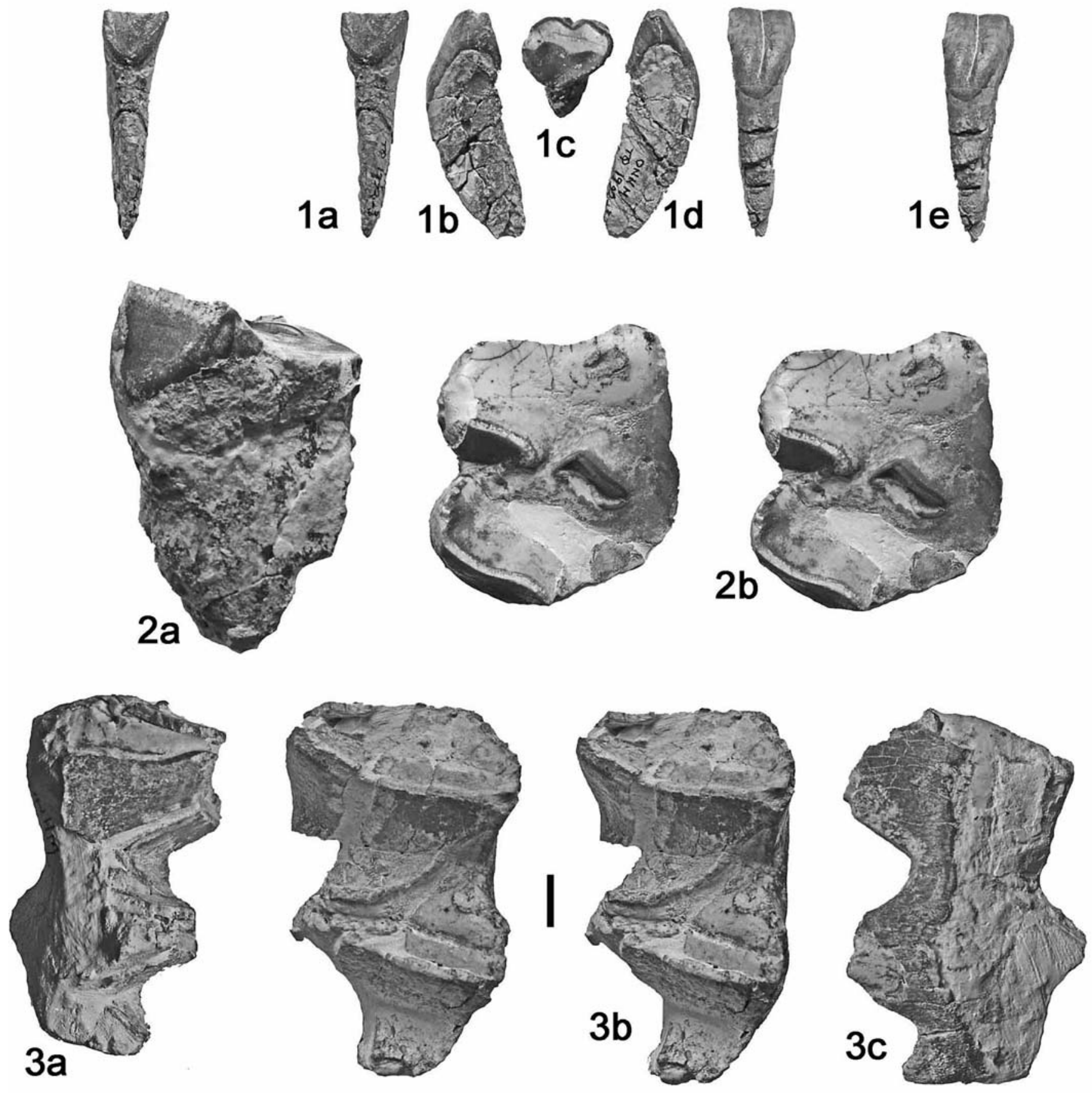

Figure 4. Arsinoitherium andrewsi from Taqah, Oman. 1) ONHM TQ 1992-3, left p/1, (1a) stereo lingual view, (1b) distal view, (1c) occlusal view, (1d) mesial view, (1e) stereo buccal view. 2) ONHM TQ 1992-2, deeply worn right M1/, (2a) distal view, (2b) stereo occlusal view. 3) ONHM TQ 1992-1, left m/3, (3a) buccal view, (3b) stereo occlusal view, (3c) lingual view (scale: $10 \mathrm{~mm}$ ).

the reported differences in dimensions of the teeth could be due to different ways of measuring the teeth related to the peculiar style of hypsodonty and crown curvature that typify teeth of this genus which results in very divergent occlusal length/breath proportions at different wear stages.

\subsection{Biogeography and Biochronology}

Arsinoitheres have been recorded from localities in northern, equatorial and southern Africa ranging in age from Middle Eocene to Late Oligocene (Pickford et 


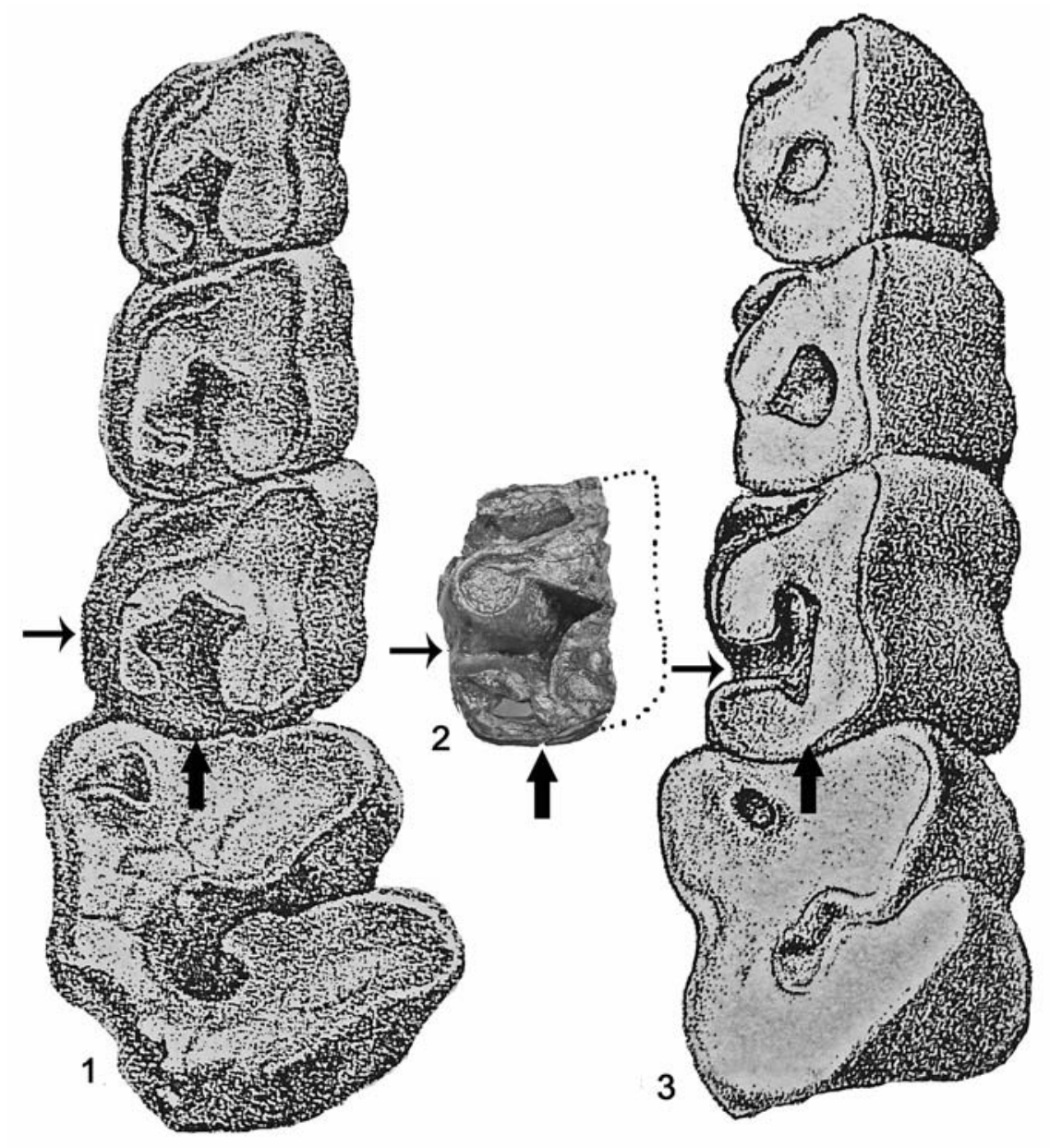

Figure 5. Comparison of left upper cheek teeth of Arsinoitherium from the Fayum, Egypt and Thaytiniti, Oman. 1) NHMUK M 8461, left $\mathrm{P} 2 /-\mathrm{M} 1 /$ (holotype of Arsinoitherium zitteli). 2) ONHM TN 1992-3, right P4/ (reversed for comparison). 3) NHMUK M 8463, left P2/-M1/ attributed to Arsinoitherium andrewsi. Note the differences between lingually closed medifossette in 1) and the lingually opening medifossette in 2) and 3) (small arrows) combined with distally open medifossette in 1) but medifossette closed distally in 2) and 3) (thick arrows). Images 1) and 3) are reproduced from Andrews (1906). Note the slightly different orientations of the images in Andrews (1906) in which 1) was drawn with the occlusal surface horizontal, while in 3) the occlusal surface slopes slightly lingually. al., 2008; Sanders et al., 2010) (Fig. 2). Namatherium blackcrowense is a primitive arsinoithere with wide, flaring, zygomatic arches and relatively brachyodont cheek teeth. It is known from a partial skull from the Middle Eocene epikarst deposits at Black Crow, Namibia (Pickford et al., 2008).

The genus Arsinoitherium has been reported from Late Eocene to Late Oligocene strata, principally from the Fayum deposits of Egypt (Court, 1992a, b) but also from Dur At-Talah, Libya, and Chilga, Ethiopia (Kappelman et al., 2003; Sanders et al., 2004) as well as in younger sediments at Losodok, Kenya (Rasmussen \& Gutierrez, 2009). An arsinoithere tooth from Malembe, Angola, was described by Pickford $(1986,1987)$. A paper was submitted several years ago concerning the presence of Arsinoitherium zitteli at Oued Grigema, Tunisia, based on the distal loph of an upper third molar (Pickford, submitted) but recent events in the region seem to have delayed publication. Other remains from Late Eocene deposits at Bir Om Ali, near Chambi, Tunisia, were attributed to Arsinoitherium? by Vialle et al. (2013). Recently, Embrithopods have been reported from the Usfan (Late Eocene) and Shumaysi (Early Oligocene) formations on the Red Sea side of Saudi Arabia (Zalmout et al., 2012) but the fossils have not yet been described in detail, although one tooth has been figured (Zalmout et al., 2010, supplementary figure $1 \mathrm{k}, 11)$.

The Omani M3/ is compatible in dimensions and morphology to a specimen from Oued Grigema, Tunisia (Pickford, submitted) but is much bigger and more hypsodont than that of Namatherium blackcrowense from Namibia (Pickford et al., 2008).

Given the long chronological range and continent-wide distribution of arsinoitheres in Africa during the Eocene and Oligocene, the presence of the group in the Early Oligocene of the Arabian Peninsula is not surprising. Because of dental differences from Arsinoitherium zitteli, the fossils from Thaytiniti and Taqah, Oman, are excluded from this species. They are considered to belong to the species Arsinoitherium andrewsi the second species of embrithopod defined at the Fayum, Egypt (Beadnell, 1902a, b; Lankester, 1903; Andrews, 1904, 1906).

The mammalian fauna from Thaytniti and Taqah, Oman contains many taxa, which also occur in the Fayum deposits (Thomas et al., 1992, 1999). The arsinoithere fossils from Oman augment the similarities between the Oligocene faunas of the two regions. 


\subsection{Palaeoenvironment}

Abundant and diverse non-marine molluscan faunas from many localities at Thaytiniti and Taqah reveal that the palaeoenvironment in the Dhofar region of Oman during basal Oligocene times was likely to have comprised sub-humid savannah with swamps and dense stands of woodland (Pickford et al., 2014). The deposits accumulated close to sea-level, but those at Thaytiniti now stand at an altitude of over 900 metres, as a result of tectonic activity that uplifted the Dhofar Mountains some time later than the Rupelian stage (probably during the Miocene), leaving slivers of the deposits, such as those at Taqah, close to sea-level.

\section{CONCLUSIONS}

Several teeth from two Rupelian localities, Thaytiniti and Taqah, in Oman, are attributed to Arsinoitherium andrewsi, on the basis of the morphology of the $\mathrm{P} 4 /$ and $\mathrm{m} / 3$, which differ from the type specimen and other material of Arsinoitherium zitteli from the Fayum, Egypt (Andrews, 1906, pl. 4.2). This taxonomic decision is influenced by the fact that some of the the Fayum sample contains $\mathrm{P} 4 / \mathrm{s}$ similar to the Omani specimen (Andrews, 1906, pl. 2). The elongated and well-developed talonid in the Omani $\mathrm{m} / 3$ is absent in most specimens from the Fayum, but is present in one specimen curated in the MNHN, Paris. The arsinoitheres from Oman add to the list of taxa which occur in both the Early Oligocene deposits of Oman and the Fayum succession, Egypt.

\section{ACKNOWLEDGEMENTS}

Thanks to the Oman Ministry of Commerce and Industry for research authorisation, and the Oman Natural History Museum and for access to fossils in their care. The arsinoithere fossils described herein were collected during expeditions to Oman led by H. Thomas in the early 1990's, funded by the Collège de France, the French BRGM and the CNRS. Referee's comments by W. Sanders and R. Tabuce helped improve the paper, for which thanks are tendered. We thank Sorbonne Universités - CR2P, MNHN, CNRS, UPMC - Paris VI, for funding field surveys during 2013 and 2014. Thanks to the Natural History Museum, London, and the Muséum National d'Histoire Naturelle, Paris, for allowing access to fossils in their care.

\section{REFERENCES}

Al-Sayigh, A.R., Nasir, S., Schulp, A.S. \& Stevens. N.J. 2008. The first described Arsinoitherium from the Upper Eocene Aydim Formation of Oman: Biogeographic implications. Palaeoworld, 17, 41-46.

Andrews, C.W. 1904. Further notes on the mammals of the Eocene of Egypt, part II. Geological Magazine, Series $5,1,157-162$.

Andrews, C.W. 1906. A Descriptive Catalogue of the Tertiary Vertebrata of the Fayûm, Egypt. British Museum of Natural History, London.

Beadnell, J. 1902a. A preliminary note on Arsinoitherium zitteli Beadnell, from the upper Eocene strata of Egypt. Survey Department, Public Works Ministry, Cairo, National Printing Department, 1-4.

Beadnell, J. 1902b. Note on Arsinoitherium. Cairo, 1902, Geological Magazine, 10, 529.

Coster, P., Benammi, M., Mahboubi, M., Tabuce, R., Adaci, M., Marivaux, L., Bensalah, M., Mahboubi, S., Mahboubi, A., Mebrouk, F., Maameri, C. \& Jaeger, J.-J. 2012. Chronology of the Eocene continental deposits of Africa: Magnetostratigraphy and biostratigraphy of the El Kohol and Glib Zegdou Formations, Algeria. Geological Society of America Bulletin, doi: 10.1130/B30565.1.

Court, N. 1992a. A unique form of dental bilophodonty and a functional interpretation of peculiarities in the masticatory system of Arsinoitherium (Mammalia, Embrithopoda). Historical Biology, 6, 91-111.

Court, N. 1992b. The skull of Arsinoitherium (Mammalia, Embrithopoda) and the higher order interrelationships of ungulates. Palaeovertebrata, 22, 1-43.

Delmer, C. 2009. Reassessment of the generic attribution of Numidotherium savagei and the homologues of lower incisors in proboscideans. Acta Palaeontologica Polonica, 54, 561-580.

Kappelman, J., Rasmussen, D.T., Sanders, W., Feseha, M., Bown, T., Copeland, P., Grabaugh, J., Fleagle, J., Glantz, M., Gordon, A., Jacobs, B., Maga, M., Muldoon, K., Pan, A., Pyne, L., Richmond, B., Ryan, T., Seiffert, E., Sen, S., Todd, L., Wiemann, M. \& Winkler, A. 2003. Oligocene mammals from Ethiopia and faunal exchange between Afro-Arabia and Eurasia. Nature, 2102, 1-4

Lankester, E.R. 1903. A new extinct monster. Sphere, London, 1903, 238.

Mondegar Fernandez, J.M., Delmer, C. \& Tassy, P. 2008. El género Arsinoitherium: catalogo de la celeccion inédita del Muséum d'Histoire Naturelle de Paris y el problema del numéro de especies. Palaeontologica Nova, 291-304.

Pickford, M. 1986. Première découverte d'une faune mammalienne terrestre paléogène d'Afrique subsaharienne. Comptes Rendus de l'Académie des Sciences, Paris, Série II, 19, 1205-1210.

Pickford, M. 1987. Recognition of an early Oligocene or late Eocene mammal fauna from Cabinda, Angola. Musée Royal de l'Afrique Centrale (Belgique), Rapport Annuel du Département de Géologie et de Mineralogie, 19851986, 89-92. 
Pickford, M., Gheerbrant, E., Sen, S., Roger, J. \& Al-Sumainai, Z. 2014. Palaeogene non- marine molluscs from Oman: implications for the timing of uplift of the Dhofar Plateau and the opening of the Red Sea and Gulf of Aden. In: Tectonic Evolution of the Oman Mountains (eds. Rollinson, H.R., Searle, M.P., Abbasi, I.A., Al-Lazki, A. \& Al-Kindi, M.H.). Geological Society, London, Special Publications, 392, 89-102. http://dx.doi.org/10.1144/SP392.

Pickford, M., Senut, B., Morales, J., Mein, P. \& Sanchez, I.M. 2008. Mammalia from the Lutetian of Namibia. Memoir of the Geological Survey of Namibia, 20, 465-514.

Rasmussen, D.T. \& Gutiérrez, M. 2009. A mammalian fauna from the late Oligocene of northwestern Kenya. Palaeontographica, Abteilung, A 288, 1-52.

Roger, J., Platel, J., Bourdillon de Grissac, C. \& Cavelier, C. 1994. Geology of Dhofar: Geology and Geodynamic Evolution during the Mesozoic and Cenozoic. M.P.M. Geological Documents, Ministry of Petroleum and Minerals, Muscat, Sultanate of Oman.

Roger, J., Sen, S., Thomas, H., Cavalier, C. \& AlSulaimani, Z. 1993. Stratigraphic, palaeomagnetic and palaeoenvironmental study of the Early Oligocene vertebrate locality of Taqah (Dhofar, Sultanate of Oman). Newsletters on Stratigraphy, 28, 93-119.

Sanders, W. J., Kappelman, J. \& Rasmussen D.T. 2004. New large-bodied mammals from the late Oligocene site of Chilga, Ethiopia. Acta Palaeontologica Polonica, 49, 365-392.

Sanders, W., Rasmussen, D.T. \& Kappelman, J. 2010. Embrithopoda. In: Cenozoic Mammals of Africa (eds. Werdelin, L. \& Sanders, W.). University of California Press, Berkeley, Los Angeles, London, 115-122.

Seiffert, E. 2010. Chronology of Paleogene Mammals. In: Cenozoic Mammals of Africa (eds. Werdelin, L. \& Sanders, W.). University of California Press, Berkeley, Los Angeles, London, 19-26.

Seiffert, E., Nasir, S., Al-Harthy, A., Groenke, J., Kraatz, B., Stevens, N. \& Al-Sayigh, A. 2012. Diversity in the later Paleogene proboscidean radiation: a small barytheriid from the Oligocene of Dhofar Governorate, Sultanate of
Oman. Naturwissenschaften, 1-9, doi: 10.1007/s00114011-0878-9.

Thomas, H., Roger, J., Sen, S., Bourdillon de Grissac, C. \& Al-Sulaimani, Z. 1989. Découverte de vertébrés fossiles dans l'Oligocène inférieur du Dhofar (Sultanat d'Oman). Geobios, 22, 101-120.

Thomas, H., Roger, J., Sen, S. \& Al-Sulaimani, Z. 1992. Early Oligocene vertebrates from Dhofar (Sultanate of Oman). Geology of the Arab World, Cairo University, Cairo, 283-293.

Thomas, H., Roger, J., Sen, S., Pickford, M., Gheerbrant, E., Al-Sulaimani, Z. \& Al-Busaidi, S. 1999. Oligocene and Miocene terrestrial vertebrates in the southern Arabian Peninsula (Sultanate of Oman) and their geodynamic and palaeogeographic settings. In: Fossil Vertebrates of Arabia (eds. Whybrow, P. \& Hill, A.). Yale University Press, New Haven, 430-442.

Vialle, N., Merzeraud, G., Delmer, C., Feist, M., Jiquel, S., Marivaux, L., Ramdarshan, A., Vianey-Liaud, M., Essid, E.-M., Marzougi, W., Ammar, H.K. \& Tabuce, R. 2013. Discovery of an Embrithopod mammal (Arsinoitherium?) in the Late Eocene of Tunisia. Journal of African Earth Sciences, 87, 86-92.

von Koenigswald, W. 2013. Unique differentiation of radial enamel in Arsinoitherium (Embrithopoda, Tethytheria). Historical Biology: An International Journal of Paleobiology, 25, 183-192.

Zalmout, I.S., Sanders, W.J., MacLatchy, L., Gunnell, G., Al-Muffareh, Y.A., Ali, M.A., Nasser, A.-A.H., Al-Masari, A.M., \& Al-Sobhi, S.A., 2010. New Oligocene primate from Saudi Arabia and the divergence of the apes and Old World monkeys. Nature, 46, 360-364, doi: 10.1038/ nature09094.

Zalmout, I.S., Gunnell, G., Al-Mufarreh, Y., Ali, M.A., Nasser, A.-A.H., Matari, A., Jamalaldeen, A. \& Gingerich, P. 2012. Oligocene Anthracotheriidae (Artiodactyla) from the Usfan and Shumaysi Formations, Western Saudi Arabia. Geological Society of America Abstracts with Programs, 44(7), 605 . 